\title{
In vitro istraživanje apikalnog mikropropuštanja pet tehnika punjenja kanala
}

\section{A Comparative in Vitro Study of Apical Microleakage of Five Obturation Techniques}

Zavod za endodonciju Katoličkog sveučilišta u Valenciji, Španjolska

Department of Endodontics, Catholic University of Valencia, Spain

Sažetak

Svrha: Željelo se usporediti tehnike punjenja kanala - od lateralne kondenzacije do ostalih tehnika kondenzacije punila koje uključuju fizičke (temperatura: Soft-Core $®$, Obtura IIß) i kemijske promjene (condensation: Guttaflow $®$, Resilon $($ ) te njihov konačni utjecaj na dimenzijsku stabilnost i apikalno mikropropuštanje. Materijali i metode: Obrađeno je 212 zuba izvađenih iz ortodontskih ili parodontoloških razloga te su nasumce podijeljeni u pet grupa po njih 40. Odabrano je i po šest uzoraka za pozitivnu i negativnu kontrolu. Svi zubi obrađeni su sistemom Hero 642 i za svaku je grupu uporabljena različita tehnika punjenja: lateralna kondenzacija, Obtura $I I \circledR$, Soft-Core $\AA^{\circledR}$, Guttaflow ${ }^{\circledR}$ ili Resilon $®$. Zatim su svi uzorci uronjeni u crnu tintu te nakon 72 sata obrađeni Robertsonovom tehnikom transparentizacije. Nakon toga je filtracija tinte izmjerena stereoskopskim mikroskopom. Za statističku analizu korištena je analiza varijabilnosti i post-hoc testiranje. Rezultati: Grupa zuba obrađena tehnikom Soft-Core® imala je značajno veće mikropropuštanje u odnosu na ostale tri skupine kod kojih smo se koristili ostalim tehnikama. Rezultati mikropropuštanja bili su slični. Zaključak: U ovom istraživanju zubi obrađeni tehnikom Soft-Core® imali su veće apikalno mikropropuštanje nego oni kod kojih su primijenjene ostale tehnike.
Zaprimljen: 9. travnja 2014 Prihvaćen: 2. lipnja 2014.

Adresa za dopisivanje Manuel Monterde Catholic University of Valencia Department of Endodontics Valencia, Spain

clinicamonterde@gmail.com

\section{Ključne riječi}

zub, apeks; zubno propuštanje; korijenski kanal, brtvljenje; korijenski kanala, materijali za punjenje

\section{Uvod}

Najvažnije je pri endodontskom tretmanu postići potpuno trodimenzionalno punjenje ili brtvljenje korijenskih kanala kako bi se spriječilo mikropropuštanje bakterija i štetnih bakterijskih tvari $(1,2)$. Kako bi se to uspjelo, kao materijal za punjenje rabi se polutvrda ili plastična gutaperka (3). Kako gutaperka sama ne može potpuno zabrtviti kanal, koristimo se i cementom kako bi se povezala s dentinom. Pritom cement ispunjava sve nepravilnosti između zida korijenskog kanala i štapića gutaperke (4). Cement je vrlo važan u punjenju kanala jer zbog njegove resorpcije nastaje mikrofiltracija, što na kraju rezultira uspjehom ili neuspjehom endodontske terapije (5).

Lateralnom kondenzacijom koriste se stomatolozi i specijalisti već desetljećima i taj se način izučava na većini stomatoloških fakulteta $(6,7)$. No razvijeni su novi materijali i tehnike kako bi se poboljšalo apikalno brtvljenje. Primjerice, tehnika Obtura $\mathrm{II}^{\bullet}$ (Obtura Spartan, Fenton, MO, SAD) koristi se termoplastičnom gutaperkom koja se ubrizgava u kanal zajedno s cementom koji podnosi visoke temperature. Soft-Core (Soft-Core ${ }^{\bullet}$ System, Kopenhagen, Danska) se sastoji od biokompatibilne plastične jezgre okružene afazom termoplastične gutaperke koja se zagrijava u pećnici. Ova se tehnika kombinira s uobičajenim cementom za pu-

\section{Introduction}

One of the main objectives of endodontic treatment is to achieve full three-dimensional filling or obturation of the root canals, in order to prevent the microleakage of bacteria and their waste products $(1,2)$. To achieve this effect, guttapercha is used as filler material, whether in semisolid or plastic state (3). On the other hand, since guttapercha does not effectively seal the canal when used alone, we must use a sealing cement in an attempt to adhere the material to the dentin, and for filling the irregularities and small discrepancies between the guttapercha and the canal walls (4). Sealing cement plays a very important role, since its dissolution increases microfiltration, and can therefore lead to endodontic treatment failure (5).

The lateral condensation method has been used for decades by most dentists and specialists, and it is the technique taught in most dental schools (6,7). New materials and techniques have been introduced in an attempt to improve apical sealing. In this context, Obtura II ${ }^{\bullet}$ (Obtura Spartan, Fenton, MO, USA) is a thermoplastic guttapercha product that is injected into the canal and is combined with a sealing cement capable of resisting high temperatures. The Soft-Core technique (Soft-Core ${ }^{\bullet}$ System, Copenhagen, Denmark) in turn consists of a biocompatible plastic stem enveloped by phase $\alpha$ thermo- 
njenje. Tehnika Guttaflow (Roeko, Coltene / Whaledent, Njemačka) tehnika je hladnog fluida kod koje se u jednom proizvodu kombinira cement i štapić gutaperke. Toplina nije potrebna da bi se gutaperka smekšala i postigla kemijsku kondenzaciju. Za ovu tehniku nije potreban konvencionalni cement. Resilon ${ }^{\circledR}$ (Pentron Technologies, Wallingford, CT, $\mathrm{SAD}$ ) novi je materijal za punjenje korijenskih kanala, a proizveden je od polimera polycaprolactama koji se mogu vezivati za dentinske adhezive i metakrilatne smole. Kao cement uporablja se primer koji kondicionira dentin i adheziv koji se vezuje za Resilon ${ }^{\oplus} s$ jedne strane i korijenski kanal $s$ druge strane, te tako nastaje jedinstveni trodimenzionalni blok koji brtvi kanal.

U ovom istraživanju uspoređuju se apikalna brtvljenja pet opisanih tehnika: lateralne kondenzacije, Obtue $\mathrm{II}^{\odot}$, SoftCorea ${ }^{\oplus}$, Guttaflowa ${ }^{\oplus}$ i Resilona ${ }^{\circledR}$.

\section{Materijali i metode}

Odabrano je ukupno 212 zuba izvađenih zbog ortodontskih ili parodontoloških razloga. Najprije je sa svih njihovih površina očišćen kamenac i univerzalnom kiretom uklonjeni su ostatci parodontnog tkiva. Nakon toga su do instrumentacije bili pohranjeni u fiziološkoj otopini.

Inicijalna trepanacija obavljena je okruglim svrdlom, a kada je dosegnuta komora pulpe, nastavljen je rad svrdlom Endo-Z. Pristup korijenskim kanalima osiguran je iglicama K-file 20 (Maillefer, Ballaigues, Švucarska). Radna duljina određena je kada je iglica dosegnula apikalni foramen te vraćena $0,5 \mathrm{~mm}$, nakon čega je izmjerena duljina. Za čišćenje i širenje korijenskih kanala korišten je rotirajući sistem Hero 642 (Micromega, Besançon, Francuska). Postupak je počeo iglicom broj 20 koniciteta od 6 posto na duljini $4 \mathrm{~mm}$ kraćoj od radne duljine kako bi se proširila koronarna trećina korijenskog kanala. Ako su kanali jako široki, treba se koristiti iglicama broj 25 i 30 koniciteta od 6 posto. U slučaju da je kanal eliptičnog presjeka, uglavnom u donjim incizivima i kaninima uporablja se Gates-Gliddenovo svrdlo broj 3 kako bi se očistila i proširila koronarna trećina, nakon čega slijedi instrumentacija svrdlima 20, 25 i 30 koniciteta od 4 posto u punoj radnoj duljini. Veće iglice, kao što su broj 35, 40 i 45, preporučuju se kod jako širokih kanala. Između svake instrumentacije kanali su dobro isprani 0,2-postotnom otopinom klorheksidinova glukonata. Nakon instrumentacije kanali su osušeni papirnatim štapićima, a apeksi još jedanput probijeni kako bi se osigurala prohodnost. Šest zuba bilo je uvršsteno u pozitivnu kontrolu i isto toliko u negativnu. Ostali uzorci nasumce su podijeljeni u pet grupa:

- Grupa 1: 40 zuba ispunjenih tehnikom lateralne kondenzacije

- Grupa 2: 40 zuba ispunjenih tehnikom Soft-Core

- Grupa 3: 40 zuba ispunjenih tehnikom Obtura I $^{\odot}$

- Grupa 4: 40 zuba ispunjenih tehnikom Guttaflow ${ }^{\circ}$

- Grupa 5: 40 zuba ispunjenih tehnikom Resilon ${ }^{\circ}$

Pozitivna kontrolna skupina sastojala se od zuba čiji su korijenski kanali instrumentirani, ali nisu ispunjeni. To je učinjeno zato da bi se potvrdila vjerodostojnost eksperimentalne metode filtracije jer tinta nesmetano prodire u neispu- plastic guttapercha that is heated in an oven. It is also used with common sealing cement. The Guttaflow ${ }^{\oplus}$ system (Roeko, Coltene / Whaledent, Germany) is a cold fluid technique combining the sealing agent and guttapercha in the same product. Heat is not required for softening the guttapercha and chemical condensation. No conventional sealing cement is therefore needed. Lastly, Resilon ${ }^{\circledast}$ (Pentron Technologies, Wallingford, CT, USA) is a new root filling material composed of polycaprolactam polymers that are able to bind to dentin adhesives and resins in a methacrylate base. As sealing cement, use is made of a primer that conditions the dentin and of a dentin adhesive that binds the Resilon ${ }^{\circ}$ tips to the walls of the canal, forming a single three-dimensional sealing block.

The present study compares the apical sealing capacity of five root canal obturation techniques: lateral condensation, Obtura $\mathrm{II}^{\ominus}$, Soft-Core ${ }^{\oplus}$, Guttaflow ${ }^{\oplus}$ and Resilon ${ }^{\oplus}$.

\section{Materials and methods}

A total of 212 single-root teeth removed for orthodontic or periodontal reasons were used. Calculus and adhered periradicular tissues were mechanically removed with a universal curette, and the teeth were stored in saline solution until instrumentation.

The first opening was made with a round drill, followed by the use of an Endo- $Z$ bur once the pulp chamber was reached. Access to the root canal was confirmed by inserting a size $20 \mathrm{~K}$-file (Maillefer, Ballaigues, Switzerland). The working length was then established by displacing the file through the apical foramen, withdrawing it to within 0.5 $\mathrm{mm}$ of the latter, and registering the resulting length. For cleaning and conformation of the canals, Hero 642 continuous rotary endodontic system (Micromega, Besançon, France) was used. The procedure was started using the number 20 file with a conicity of $6 \%$ at $4 \mathrm{~mm}$ from the working length, to widen the coronal third. In the case of very wide canals we used files of numbers 25 and 30 , with a conicity of $6 \%$. In elliptic canals, such as those of the lower incisors and canines, number 3 Gates-Glidden burs were employed for cleaning the coronal third, followed by the use of files of numbers 20,25 and finally 30 with a conicity of $4 \%$ directly at the working length. Larger files (sizes 35, 40 and 45) were used in the case of very wide canals. Between each file size the canal was abundantly irrigated with $0.2 \%$ chlorhexidine digluconate. Once instrumented, the canals were dried with paper tips, and the apexes were again surpassed to confirm their permeability. Six teeth were used as positive controls, and another 6 teeth as negative controls. The rest of the samples were randomized to 5 groups as follows:

- Group 1: 40 teeth obturated with the lateral condensation technique

- Group 2: 40 teeth obturated with Soft-Core ${ }^{\oplus}$

- Group 3: 40 teeth obturated with Obtura II ${ }^{\circ}$

- Group 4: 40 teeth obturated with Guttaflow ${ }^{\circ}$

- Group 5: 40 teeth obturated with Resilon

The positive controls were instrumented but not obturated, and were used to confirm the validity of the experimental filtration model used in the study, since it allows penetration 
njeni korijenski kanal. U negativnoj kontrolnoj skupini bili su zubi $s$ instrumentiranim i potpuno ispunjenim korijenskim kanalima te premazani lakom za nokte. Ova skupina služila je kako bi se kontroliralo da tinta koja uđe u kanal prođe samo nelakiranim apikalnim foramenom i nijednim drugim potencijalnim smjerom.

Zubi u grupi broj 1 ispunjeni su tehnikom lateralne kondenzacije. Nakon sušenja kanala odabrali smo master-apikalnu gutaperku. Cement je zamiješan (AH Plus, Dentsply / Maillefer, Ballaigues, Switzerland) i unesen u kanal lentulo-spiralom. Master-gutaperka impregnirana je cementom i unesena u kanal do radne duljine, a zatim se blagim oscilirajućim pokretima omogućilo prodiranje cementa. Nakon toga smo ručnim proširivačima broj 30 ili 25 na $1 \mathrm{~mm}$ kraće od radne duljine komprimirali gutaperku. U prostor nastao umetanjem proširivača umetali smo štapiće gutaperke broj 20 sve dok kanal nije bio potpuno ispunjen. Koronalni višak štapića gutaperke uklonjen je vrućim instrumentom, a zatim je učinjena vertikalna kondenzacija instrumentom MachtouPlugger 1-2 (VDW, München, Njemačka). U trepanacijski otvor stavljen je privremeni ispun (Cavit ${ }^{\circ}, 3 \mathrm{M}$ Espe, Njemačka).

Zubi u grupi 2 ispunjeni su termoplastičnom gutaperkom s plastičnom jezgrom (Soft-Core ${ }^{\oplus}$, Dental Production Aps., Kopenhagen, Danska). Veličina obturatora prekontrolirana je instrumentima za provjeru duljine i širine. Nakon isušivanja kanala zamiješan je cement $\mathrm{AH}$ Plus Cavit ${ }^{\circledR} \mathrm{i}$ unesen u kanal, a obturator je stavljen u pećnicu (Soft-Core ${ }^{\circ}$ Oven). Nakon što se gutaperka zagrijala do određene temperature, obturator je izvađen iz pećnice i njegov je vrh impregniran cementom te je unesen u kanal u punoj radnoj duljini. Nakon nekoliko sekundi višak štapića odrezan je okruglim svrdlom, a trepanacijski kavitet ispunjen privremenim cementom Cavit ${ }^{\circ}$.

Treća skupina od 40 zuba ispunjena je tehnikom Obtura II ${ }^{\circ}$ (Obtura S.A., Fenton, MO, SAD). Cement (AH Plus, Dentsply/Maillefer, Ballaigues, Švicarska) unesen je u kanal lentulo-spiralom. Nakon što je termostat na pištolju pokazao $200^{\circ} \mathrm{C}$ ubrizgali smo rastopljenu gutaperku u kanal tako da smo kanilu pozicionirali na spoju srednje i apikalne trećine duljine korijenskog kanala, otprilike $5 \mathrm{~mm}$ od apeksa. Nakon toga pristupili smo vertikalnoj kondenzaciji punila s pomoću vertikalnog kondenzera B 60 (Maillefer, Ballaigues, Śvicarska). Nakon toga postupka kanila je ponovno umetnuta kako bismo kanal ispunili do kraja, polako povlačeći je van dok se kanal ispunjavao materijalom. Višak materijala uklonjen je vrućim instrumentom, a trepanacijski otvor ispunjen je privremenim ispunom Cavit ${ }^{\circ}$.

Zubi u grupi 4 ispunjeni su tehnikom Guttaflow ${ }^{\oplus}$ (Roeko, Coltène / Whaledent). Nakon isušivanja kanala, umetnut je master-štapić te je provjereno je li odgovara. Kapsula je aktivirana stiskanjem oba kraja prema unutra. Njezin je bijeli dio uklonjen i stavljena je 30 sekundi u amalgamator (Ventura Mix) zbog standardne frekvencije vibracije. Nakon vibriranja kapsula je uklonjena, kao i zelena jezgra s jedne strane te je montiran vrh za aplikaciju. Nakon toga pričvršćena je na pištolj (nalazi se u kompletu), a njegov je okidač bio pritisnut dok materijal nije počeo teći iz kapsule. Mali dio ubrizgan je of the ink into the root canal in the absence of filler material. In contrast, the negative controls were instrumented, obturated and entirely coated with nail varnish. Those teeth were used to confirm that when ink is found within the canal it is because it has penetrated through the non-varnished apical foramen, not through any other route or access.

The teeth in group 1 were obturated using the lateral condensation technique. After drying the canal, we selected the master apical guttapercha. Sealing cement (AH Plus, Dentsply / Maillefer, Ballaigues, Switzerland) was prepared and inserted into the canal with a lentulo. We then also impregnated the master cone, positioning it to the working length, and applying small oscillating movements to facilitate penetration of the cement. Number 30 or 25 digital spreaders were used for compacting to one millimeter short of the working length. In the space left by the condenser we then inserted an accessory number 20 guttapercha points and continued successively until complete obturation of the canal. Coronal gutta-percha was removed with a hot instrument and later to make vertical condensation with Machtou-Plugger 1-2 (VDW, München, Germany). The access cavity was filled with provisional obturating cement (Cavit ${ }^{\circ}, 3 \mathrm{M}$ Espe, Germany).

The teeth in group 2 were obturated with thermoplastic guttapercha containing a plastic stem (Soft-Core ${ }^{\bullet}$, Dental Production Aps., Copenhagen, Denmark). The size of the obturator to be used was checked with the verifiers. After drying of the canal, AH Plus Cavit ${ }^{\circledR}$ sealing cement was inserted and the obturator was placed in the oven (Soft-Core ${ }^{\circ}$ Oven). Once the guttapercha was heated to the required temperature, the obturator was removed from the oven, and the tip was impregnated with sealing cement and inserted into the canal to the working length. After a few seconds, the surplus stem was cut with a round drill, and the access cavity was filled with Cavit?.

The third group of 40 teeth was obturated using the Obtura II $^{\circ}$ technique (Obtura S.A., Fenton, MO, USA). Cement (AH Plus, Dentsply / Maillefer, Ballaigues, Switzerland) was inserted into the canal with the help of a lentulo. Once the pistol display indicated that $200^{\circ} \mathrm{C}$ had been reached, we injected guttapercha positioning the cannula at the junction between the apical third and the middle third, approximately $5 \mathrm{~mm}$ from the apex. After filling, the tip was removed and a B 60 vertical condenser (Maillefer, Ballaigues, Switzerland) was used for vertical compaction of the guttapercha. The cannula was then again inserted to fill the rest of the canal, gently withdrawing it as the canal was gradually filled. Following this operation, the excess material was removed with a hot instrument, followed by sealing of the access cavity with Cavit?.

The teeth in group 4 were obturated with Guttaflow ${ }^{\circ}$ (Roeko, Coltène / Whaledent). After drying of the canal, we inserted the master cone and confirmed that it was adequate. The capsule was then activated by pressing both ends inwards. The white hood was removed from the capsule and placed in an amalgam vibrator (Ventura Mix) for 30 seconds at standard vibration frequency. After completing the cycle, the capsule was extracted, the green stem at one end was removed, and we fitted the application tip. The capsule was 
u kanal. Master-štapić impregniran je gutaperkom i umetnut na radnu duljinu. Ostatak kanala ispunjen je tekućim materijalom. Višak je uklonjen vrućim instrumentom. Trepanacijski kavitet ispunjen je Cavitom ${ }^{\circ}$.

Zubi u grupi 5 ispunjeni su tehnikom Resilon ${ }^{\circ}$ Samojetkajući primer (Epiphany primer, Pentron Clinical Technologies, Wallingford, CT, SAD) unesen je mikročetkicom u trajanju od 30 sekundi. Cement za punjenje stavljen je master-štapićem u kanal pokretima povlačenja i sabijanja. Poslije toga unesen je master-štapić Resilon ${ }^{\circledR}$ na već određenu radnu duljinu te je nastavljena lateralna kondenzacija. Nakon završstka punjenja svaki kanal naknadno je polimeriziran 40 sekundi kako bi se postiglo imedijatno inicijalno koronarno brtvljenje na ulazu u kanal, a zatim se cement nastavio polimerizirati sljedećih 25 minuta.

Nakon što su ispunjeni svi zubi u svim skupinama, svaki je obojen lakom za nokte osim zadnja $3 \mathrm{~mm}$ apikalno. Zatim je položen u posudicu s crnom tintom. Zatim su nakon 72 sata izvađeni i dobro isprani vodom. Lak za nokte uklonjen je oštrom špatulom.

Robertsonova tehnika transparentizacije zuba (8) provedena je kako bi se procijenila filtracija tinte.

Nakon toga postupka zubi su pregledani stereoskopskim mikroskopom (Nikon SMZ 2T), s povećanjem od 100 puta. Šablona za mjerenje na okularu korišstena je kako bi se izmjerila filtracija tinte u kanalima. Uzorci su fotografirani aparatom NIKON D 90 postavljenim na mikroskopu. Rezultati mjerenja svakog uzorka (izraženi u $\mathrm{mm}$ ) pohranjeni su u program Microsoft Excell.

Statistička analiza obavljena je (ANOVA i Post-hoc test) u SPSS verziji 12.0 statistickog paketa (SPSS Inc., Chicago, IL, SAD). mounted in the pistol supplied with the kit, and the trigger was pulled until the material started to flow. We then inserted a small portion into the canal. The master apical cone was impregnated with guttapercha and inserted to the working length. The rest of the canal was filled with the fluid material, and the excess was removed with a hot instrument, followed by sealing of the access cavity with Cavit'.

Lastly, the teeth in group 5 were obturated with Resilon . The self-etching primer (Epiphany primer, Pentron Clinical Technologies, Wallingford, CT, USA) was placed in a well for direct application within the root canal using a microbrush for 30 seconds. The sealing cement was inserted in the canal with the master cone well impregnated, and impulsion-traction movements were applied. We then inserted the Resilon ${ }^{\bullet}$ master cone to the previously determined working length, and performed the lateral condensation technique. After completing obturation, each canal was photopolymerized for 40 seconds to achieve immediate initial coronal sealing at the entrance, followed by total polymerization of the rest of the cement over the next 25 minutes.

Once all the groups of teeth were obturated, we painted the entire root surface with two layers of nail varnish, except for the three most apical millimeters. Each sample was then placed in an empty guttapercha or paper tips tube containing black ink. After 72 hours of exposure to the ink, the samples were rinsed with abundant water and the nail varnish was removed with a sharp spatula.

Transparentization of the teeth was then carried out in order to evaluate filtration, based on the technique described by Robertson (8).

Following this process, the teeth were examined with the stereoscopic microscope (Nikon SMZ 2T) under x100 magnification. The precision grid of the eyepiece was used to measure any ink filtration into the canal. The samples were photographed with a NIKON D90 camera fitted to the microscope. The filtration results of each sample (expressed in $\mathrm{mm}$ ) were recorded using a Microsoft Excel spreadsheet.

The statistical analysis of the results (ANOVA and Posthoc tests) was carried out using the SPSS version 12.0 statistical package (SPSS Inc., Chicago, IL, USA).

\section{Results}

A data dispersion chart was plotted to gain an overview of the behavior of the samples (Figure 1). The vertical axis shows the microleakage (in $\mathrm{mm}$ ), while the horizontal axis indicates the obturation techniques used. The groups were seen to behave differently, with important dispersion that proved greatest in the Soft-Core group and smallest in the Obtura II $^{\bullet}$ group. The Soft-Core ${ }^{\bullet}$ technique yielded a mean filtration of $1.16 \mathrm{~mm}$, while lesser values were recorded for the rest of the techniques: Guttaflow ${ }^{\oplus}(0.49 \mathrm{~mm})$, lateral condensation $(0.33 \mathrm{~mm})$, Obtura $\mathrm{II}^{\oplus}(0.21 \mathrm{~mm})$ and Resilon ${ }^{\bullet}(0.15 \mathrm{~mm})$. Analysis of variance (ANOVA) revealed significant differences between the means corresponding to the different groups. Post-hoc testing showed the Soft-Core ${ }^{\oplus}$ technique to exhibit significant differences versus the other groups, with no differences among the rest of the groups (Table 1). 


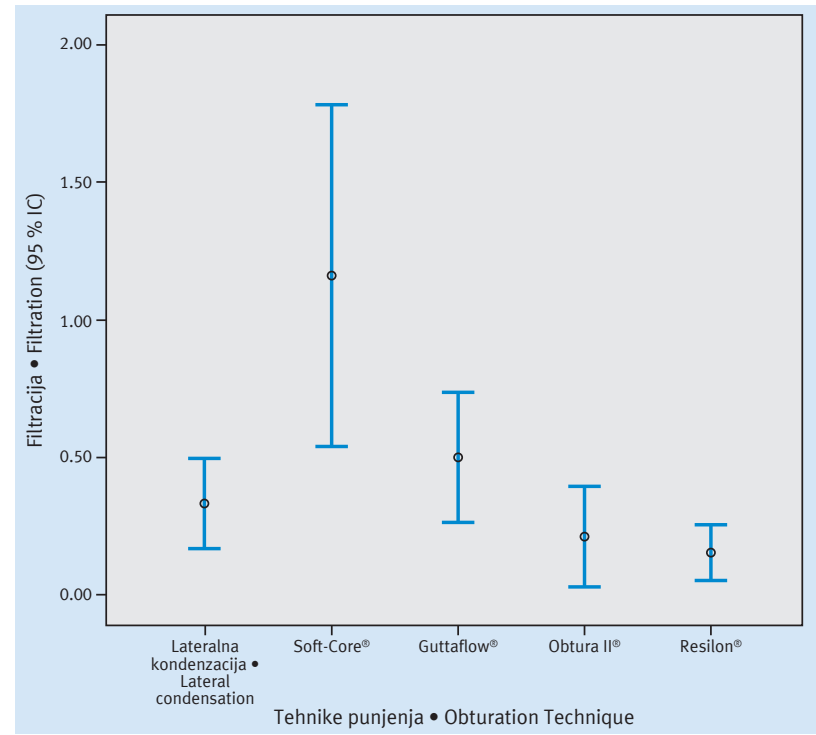

Slika 1. Disperzija podataka - vrijednosti filtracije nakon uporabljenih različitih tehnika punjenja

Figure 1 Dispersion chart showing filtration with the different obturation techniques.

Tablica 1. Post-hoc analiza srednjih vrijednosti filtracije

Table 1 Post-hoc analysis of mean filtration.

\begin{tabular}{l|l|l|l|l|l|l}
\multirow{5}{*}{ Soft-Core } & $\begin{array}{l}\text { Lateralna kondenzacija } \\
\text { Lateral condensation }\end{array}$ & $0.83025^{*}$ & 0.22343 & 0.003 & 0.1959 & 1.4646 \\
\cline { 2 - 8 } & Guttaflow & $0.66175^{*}$ & 0.22343 & 0.034 & 0.0274 & 1.2961 \\
\hline & Obtura II $^{\circ}$ & $0.94925^{*}$ & 0.22343 & 0.000 & 0.3149 & 1.5836 \\
\cline { 2 - 8 } & Resilon $^{\circ}$ & $1.00800^{*}$ & 0.22343 & 0.000 & 0.3736 & 1.6424 \\
\hline
\end{tabular}

Slika 2. Uzorak napunjen tehnikom Soft-Core ${ }^{\ominus}$; vidi se prodiranje tinte između zida korijenskog kanala i materijala za punjenje; lateralni kanali koji nisu ispunjeni materijalom za punjenje također su pokazivali prodiranje tinte

Slika 3. Uzorak iz grupe obrađene tehnikom lateralne kondenzacije
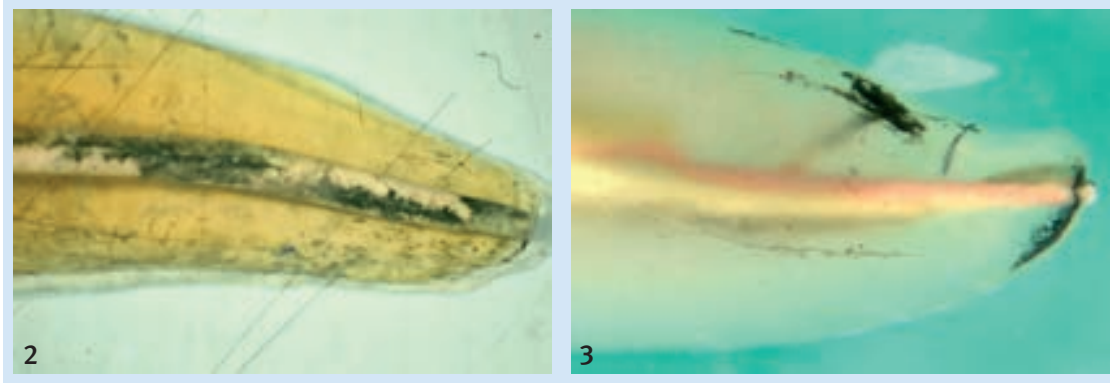

Figure 2 shows a sample obturated with the Soft-Core technique. The ink was seen to have penetrated between the wall of the root canal and the filler material. The non-obturated lateral canals likewise showed ink filtration (Figure 3). This sample corresponded to the lateral condensation group.
Slika 2. Filtracija tehnikom Soft-Core ${ }^{\circledR}$ Figure 2 Filtration with the Soft-Core ${ }^{\circledR}$ technique.

Slika 3. Neispunjeni lateralni kanal Figure 3 Non-obturated lateral canal.

\section{Rasprava}

Variraju procjene apikalnog mikropropuštanja na uzorcima obrađenima različitim tehnikama punjenja kanala. Odabrali smo metodu transparentizacije zuba zato što je jednostavna i u cijelosti standardizirana: potrebni materijali dostupni su i jeftini, nisu potrebni komplicirani uređaji i uzorci ne propadaju kao što se događa nakon uzdužnog ili poprečnog rezanja zuba.

De Moor i suradnici (9) usporedili su tri metode punjenja: lateralnu kondenzaciju i vertikalnu kondenzaciju te SoftCore ${ }^{\bullet}$. Pritom su se koristili tintom i transparentizacijom za

\section{Discussion}

Different methods have been developed for evaluating apical microleakage associated with the different root canal obturation systems. We chose tooth transparentization because it is a simple and fully standardized technique; the materials required are easily found and are inexpensive; no complex machinery is needed; and there is no sample degradation resulting from longitudinal or cross-sectioning of the teeth.

De Moor et al. (9) compared three obturation techniques: lateral condensation, vertical condensation and Soft- 
procjenu propuštanja, baš kao i mi u našem istraživanju, te su istaknuli da tehnika punjenja kanala Soft-Coreom ${ }^{\bullet}$ ima najveće vrijednosti apikalne filtracije, ali bez statistički značajnih razlika u odnosu na ostale dvije metode. U istraživanju De Moora i njegovih kolega (10) uspoređivao se cement za punjenje (AH 26) primijenjen u pet različitih tehnika punjenja: lateralnoj i vertikalnoj kondenzaciji, kondenzaciji hibridnog štapića gutaperke, te s Thermafilom ${ }^{\circ}$ i Soft-Core$\mathrm{om}^{\oplus}$. Rezultati su pokazali da Thermafil ${ }^{\circ}$ i Soft-Core ${ }^{\oplus}$ imaju veće vrijednosti koronalne filtracije negoli ostale tehnike, ali bez značajne razlike između njih samih. Apikalna filtracija bila je najveća u grupi Soft-Corea ${ }^{\circ}$. Za to istraživanje autori su uzorke najprije umočili u tintu, a zatim su ih prerezali longitudinalno te stereoskopskim mikroskopom pregledali filtraciju. U recentnom istraživanju De Moora i suradnika (11) uspoređeno je moguće brtvljenje između dvaju cemenata (AH 26 i AH Plus) korištenih u trima tehnikama punjenja kanala: lateralnoj i hibridnoj kondenzaciji i Thermafilu. Kao i prije, uzorci su uronjeni u tintu i prerezani longitudinalno. Autori nisu uočili razliku u apikalnoj filtraciji između triju grupa. Unatoč tomu tehnika Thermafil ${ }^{\bullet}$ pokazala je veću koronalnu propusnost nego ostale dvije. Naši rezultati podudaraju se $s$ navedenim rezultatima jer su najveće vrijednosti apikalne i koronalne filtracije zapažene kod tehnike koja se koristi termoplastičnim štapićem gutaperke $s$ unutarnjom jezgrom (Soft-Core ${ }^{\odot}$.

Lares i suradnici (12) usporedili su tehniku Thermafil ${ }^{\circ} s$ lateralnom kondenzacijom te su Robertsonovom tehnikom pregledali uzorke. Njihovi rezultati bili su slični našima, ali uz statistički značajno veće vrijednosti filtracije tinte pri korištenju tehnike Thermafil ${ }^{\oplus}(\mathrm{p}=0,02)$.

Haikel i kolege (13) istraživali su apikalnu mikrofiltraciju upotrebljavajući lisozim obilježen radioaktivnim jodom. Usporedivali su lateralnu kondenzaciju, Thermafil i McSpaddenovu tehniku punjenja kanala. Uočili su razlike između lateralne kondenzacije i Thermafila ${ }^{\oplus}$, a McSpaddenova tehnika pokazala je značajno veće vrijednosti nego prve dvije.

Pommel i Camps (14) proveli su komparativno istraživanje apiklane filtracije uspoređujući System B ${ }^{\oplus}$ s ostalim četirima tehnikama: single cone, lateralnom i vertikalnom kondenzacijom te Thermafilom. Autori su se koristili fiziološkom otopinom za filtraciju i infracrvenim instrumentom za njezino mjerenje. Rezultati su pokazali da tehnike za koje se rabi plastična gutaperka imaju manje vrijednosti filtracije negoli ostale. Ističu pritom da je single cone imao najveće vrijednosti mikrofiltracije.

Abarca i suradnici (15) usporedili su lateralnu kondenzaciju s Thermafilom ${ }^{\circ}$, a koristili su se istom metodologijom kao i mi u svojem istraživanju. Njihovi rezultati nisu se statistički značajno razlikovali, ali grupa s Thermafilom ${ }^{\oplus}$ imala veće vrijednosti mikropropuštanja. Iako nije bilo statistički značajnih razlika između tehnika, Thermafil ${ }^{\circ}$ je postigao veće vrijednosti filtracije, što se podudara s našim rezultatima.

Gençoglu i suradnici (16) usporedili su lateralnu kondenzaciju, Thermafil ${ }^{\oplus}$, Quick-fill ${ }^{\ominus}$ i System B ${ }^{\ominus}$. Autori su također uporabili tintu kako bi procijenili filtraciju i rezali su uzorke horizontalno 1, 2, 3 i 4 mm od apeksa. Zaključili su da Thermafil ${ }^{\ominus}$ i Quick-fill ${ }^{\circ}$ postižu manje vrijednosti filtraci-
Core. They used ink and transparentization of the samples as in our study, and concluded that Soft-Core ${ }^{\bullet}$ showed greater apical filtration than the other two techniques, which in turn presented no statistically significant differences. In a later study, De Moor et al. (10) compared one same sealing cement (AH 26) in application to 5 different obturation techniques: lateral condensation, vertical condensation, hybrid guttapercha condensation, Thermafil ${ }^{\circ}$ and Soft-Core ${ }^{\circ}$. The results showed Thermafil ${ }^{\ominus}$ and Soft-Core ${ }^{\oplus}$ to produce greater coronal filtration than the other techniques, with no differences between them. Apical filtration was greatest in the Soft-Core ${ }^{\oplus}$ group. For this study, the authors immersed the samples in ink and then sectioned them longitudinally, with observation of filtration under the stereoscopic microscope. In a more recent publication, De Moor et al. (11) compared the sealing capacity of two cements (AH 26 and AH Plus) in relation to three different techniques: lateral condensation, hybrid condensation and Thermafil ${ }^{\circ}$. As before, the samples were immersed in ink and then sectioned longitudinally. There were no differences in apical filtration among the three groups. However, Thermafil ${ }^{\circ}$ showed greater coronal filtration than the other two techniques. Our results are largely consistent with these findings in that the greatest apical and coronal filtration values corresponded to thermoplastic guttapercha with the internal stem (Soft-Core ${ }^{\circ}$.

Lares et al. (12) also compared the Thermafil ${ }^{\oplus}$ technique with lateral condensation and used the technique developed by Robertson for observation of the samples. Their results were similar to our own, with significantly greater ink filtration values when using the Thermafil ${ }^{\bullet}$ technique $(\mathrm{p}=0.02)$.

On the other hand, Haikel et al. (13) studied apical microfiltration using lysozyme labeled with radioactive iodine, comparing lateral condensation, Thermafil ${ }^{\circ}$ and the McSpadden technique. They recorded differences between lateral condensation and Thermafil ${ }^{\circ}$, while the McSpadden technique showed significantly greater values than the other two techniques.

Pommel and Camps (14) conducted a comparative study of apical filtration with System B ${ }^{\circ}$ versus four other techniques: single cone, lateral condensation, vertical condensation and Thermafil ${ }^{\circ}$, employing saline solution as filtration marker, with measurement using an infrared device. The results showed the plastic guttapercha techniques to generate less filtration than the other two procedures - maximum microfiltration corresponding to the single cone technique.

Abarca et al. (15) compared lateral condensation with the Thermafil ${ }^{\circ}$ technique using the same methodology as in our own study. They recorded no statistically significant differences between the two groups, though the greatest microleakage values corresponded to the Thermafil ${ }^{\circ}$ group. Although there were no significant differences, the latter technique tended to produce comparatively greater filtration, in accordance with our own findings.

Gençoglu et al. (16) compared lateral condensation, Thermafil ${ }^{\circ}$, Quick-fill ${ }^{\oplus}$ and System B ${ }^{\circ}$. They also used ink to assess filtration, sectioning the samples horizontally at 1,2,3 and 4 $\mathrm{mm}$ from the apex. The authors found both Thermafil ${ }^{\circ}$ and Quick-fill $^{\bullet}$ to produce less filtration than System $B^{\bullet}$ or later- 
je nego System $B^{\bullet}$ i lateralna kondenzacija. Boussetta i kolege (17) usporedili su apikalnu filtraciju tehnike Soft-Core ${ }^{\bullet}$ i lateralne kondenzacije koristeći se metilenskim modrilom kao sredstvom filtracije s poprečnim presjecima uzoraka od 500, 1000 i $1500 \mathrm{~mm}$. Rezultati su pokazali da Soft-Core uzrokuje značajno manje vrijednosti filtracije negoli lateralna kondenzacija. Ovi rezultati razlikuju se od naših, ali moramo istaknuti da su se autori tih istraživanja koristili drugačijom metodologijom - odlučili su se za poprečne presjeke uzoraka, a ne na transparentizaciju.

Schafer o suradnici (18) objavili su istraživanje u kojem su usporedili Thermafil ${ }^{\circ}$ l lateralnu kondenzaciju uz uporabu triju različitih cemenata. Također su procijenili mogući utjecaj morfologije korijenskih kanala (i.e. zakrivljeni ili ravni kanali) nakon filtracije. Kao i u našem istraživanju, umočili su uzorke u tintu i zatim su metodom transparentizacije procijenili njezinu filtraciju. Zaključili su da je mogućnost brtvljenja u objema tehnikama slična, neovisno o cementu te da je morfologija kanala nevažna jer ne utječe na brtvljenje.

Pallares (19) te Vizgirda i suradnici (20) usporedili su lateralnu kondenzaciju s Obturom II ${ }^{\oplus}$ koristeći se istom metodologijom kao i mi u svojem istraživanju. Zaključili su da je mogućnost apikalnog brtvljenja u sistemu Obtura $\mathrm{II}^{\oplus}$ slična brtvljenju tehnikom lateralne kondenzacije. Rezultati obojice autora podudaraju se s rezultatima našeg istraživanja.

Kqiku i kolege (21) koristili su se metilenskim modrilom kao sredstvom za filtraciju te su usporedili lateralnu kondenzaciju s tehnikama Guttaflow i Resilon ${ }^{\circ}$. Rezultati su pokazali da Resilon ${ }^{\circ}$ pokazuje najbolje rezultate u usporedbi s druga dva sistema. Vasiliadis i suradnici (22) proveli su dugotrajno istraživanje (jedan tjedan i tri mjeseca) filtracije koristeći se modelom transporta fluida, uspoređujući lateralnu kondenzaciju s Guttaflowom. Nisu pronašli nikakvu razliku poslije tjedan dana ili tri mjeseca. Irala Almeida i kolege (23) uočili su, uspoređujući lateralnu kondenzaciju s hibridnom tehnikom i Guttaflowom ${ }^{\bullet}$, da nema značajne razlike između triju grupa iako su hibridnom tehnikom postigli najbolje rezultate, a Guttaflowom ${ }^{\circ}$ najlošije. Rezultati ovih istraživanja bili su slični rezultatima iz našeg istraživanja. $U$ istraživanju Elayoutia i njegovih kolega (24) istaknuta je značajna pojavnost šupljina i praznih prostora nakon korištenja Guttaflowa ${ }^{\circledR}$ negoli poslije lateralne ili vertikalne kondenzacije.

Pregledavajući literaturu o tehnici Resilon ${ }^{\circledR}$ pronađen je niz potpuno suprotnih rezultata. Tay i suradnici (25) proveli su ultrastrukturno istraživanje temeljeno na elektronskoj mikroskopiji kako bi usporedili mogućnost brtvljenja gutaperka/AH plus sistema i Resilon /Epiphany sistema. Ni jedan nije zadovoljio kriterij potpunoga apikalnog brtvljenja te su u oba zabilježeni nedostatci kao što su prazni prostor i defekt vezanja između stijenke korijenskog kanala i punila. Autori su zaključili da Resilon ${ }^{\circledR}$ nije superioran sistemu s gutaperkom kad je riječ o apikalnom brtvljenju. U istraživanju provedenom filtracijom fluida, Biggs i kolege (26) usporedili su već navedene sisteme punjenja (gutperka/AH Plus i Resilon / Epiphany) te su zaključili da među njima nema razlike u mikrofiltraciji.

Onay i kolege (27) usporedili su dva cementa za brtvljenje (AH Plus ${ }^{\circledR}$ Epiphany) i dva materijala za punjenje (guta- al condensation. Boussetta et al. (17) in turn compared apical filtration with Soft-Core versus the lateral condensation technique, using methylene blue as filtration agent and performing cross-sections at 500,1000 and $1500 \mathrm{~mm}$. The results showed Soft-Core to produce significantly less filtration than the lateral condensation technique. The findings of the above two studies differ from our own, though it must be stressed that they involve a different methodological approach, with sectioning of the samples instead of transparentization.

Schafer et al. (18) published a study in which Thermafil ${ }^{\circ}$ and lateral condensation were compared with the use of three different cements. They also evaluated the possible influence of canal morphology (i.e., curved or straight canals) upon filtration. In the same way as in our study, the authors immersed the teeth in ink, followed by transparentization of the samples. They found the apical sealing capacity of both systems to be similar, independently of the cement used, and canal morphology proved irrelevant, since it did not influence sealing.

Pallares (19) and Vizgirda et al. (20) compared the lateral condensation technique with the Obtura $\mathrm{II}^{\bullet}$ system, using the same methodology as in our study. These investigators concluded that the apical sealing capacity of the Obtura II ${ }^{\oplus}$ system is similar to that of the lateral condensation technique. The results of both authors are consistent with our own findings.

Kqiku et al. (21) used methylene blue as filtrating agent, comparing lateral condensation with Guttaflow and Resilon ${ }^{\circ}$. They found Resilon to yield better results than the other two systems. Vasiliadis et al. (22) in turn conducted a long-term (one week and three months) filtration study using a fluid transport model, comparing lateral condensation with Guttaflow. They found no significant differences between the two techniques after either one week or three months. Irala Almeida et al. (23), in a comparison of lateral condensation with the hybrid technique and Guttaflow, observed no significant differences among the three groups, though the best performance was obtained with the hybrid technique, while the poorest results corresponded to Guttaflow ${ }^{\circ}$. These studies reported findings similar to our own. In another study, Elayouti et al. (24) observed a greater presence of spaces or gaps with the Guttaflow material than with either lateral condensation or vertical condensation.

In relation to Resilon ${ }^{\oplus}$, the literature offers discordant results. Tay et al. (25) carried out an ultrastructural study based on electron microscopy to compare the sealing capacity of guttapercha / AH Plus versus Resilon / Epiphany. Neither system was seen to afford complete and tight apical sealing, and moreover both materials presented gaps or binding defects between them and the canal walls. The investigators therefore concluded that Resilon ${ }^{\oplus}$ is not superior to guttapercha in terms of apical sealing. In a study using a fluid filtration technique, Biggs et al. (26) likewise compared these two materials (guttapercha / AH Plus and Resilon / Epiphany), and concluded that there are no differences between them in terms of microfiltration.

In a study of apical sealing capacity, Onay et al. (27) compared two sealing agents (AH Plus ${ }^{\circ}$ and Epiphany) versus 
perka i Resilon ${ }^{\circ}$ ) te su ispitali njihovu mogućnost apikalnog brtvljenja. Odabrali su četiri grupe: gutaperka/AH Plus ${ }^{\circ}$, gutaperka/Epiphany, Resilon ${ }^{\circ} \mathrm{AH}$ Plus ${ }^{\circ}$ i Resilon/Epiphany. Tehnika filtracije fluida korištena je kako bi se izmjerila apikalna filtracija. Zaključili su da su najmanje filtracijske vrijednosti u grupi gutaperka/Epiphany, a slijedila je gutaper$\mathrm{ka} / \mathrm{AH}$ Plus ${ }^{\circ}$. Unatoč rezultatima, nije bilo značajne razlike između tih dviju grupa. Autori smatraju da se objema kombinacijama (to su ujedno one koje se najčešće rabe) postižu slični rezultati.

Williamson i kolege (28) usporedili su Resilon /Epiphany $s$ gutaperkom / AH Plus ${ }^{\odot}$ u odnosu na bakterijsku filtraciju koristeći se patogenim kulturama te su istražili utječe li plastičnost dvaju materijala na obturaciju kanala. Autori su se koristili hladnom lateralnom kondenzacijom i tehnikom obturacije razvijenom prema Buchananu. Zaključili su kako nema razlika između dvaju materijala ili razlika u plastičnosti štapića gutaperke i tehnike Resilon ${ }^{\circledR}$.

U istraživanju Karapinar-Kazandağa i suradnika (29) autori su usporedili sisteme za obturaciju kanala i koncept jedinstvenog bloka (single cone/cement koji zahtijeva adheziju za zidove kanala, što uzrokuje formaciju jedinstvenog bloka). Testirani su bili Resilon/Epiphany, EndoRez i Activ GP ${ }^{\odot}$. Autori su se koristili glukoznim filtracijskim modelom te zaključili, zato što nije postojala statistički značajna razlika između uzoraka, da materijali za jedinstveni blok nisu superiorni konvencionalnom sistemu gutaperka/cement.

Melih i suradnici (30) usporedili su Resilon ${ }^{ø}$ s gutaperkom/AH Plusom ${ }^{\circ}$ i gutaperkom/Acrosealom ${ }^{\oplus}$ (Septodont) kako bi procijenili filtraciju, a koristili su se metilenskim modrilom. Pritom su longitudinalno razrezali korijen kako bi obavili mjerenja. Zaključili su da sistem gutaperka/Acroseal ${ }^{\circ}$ postiže najveće vrijednosti filtracije u usporedbu s ostala dva sistema. S druge strane, nije bilo značajne statističke razlikeizmeđu Resilona ${ }^{\oplus}$ i sistema gutaperka/AH Plus ${ }^{\oplus}$, te su oba postigla odlične rezultate kad je riječ o apikalnom brtvljenju.

Dakle, rezultati ovih istraživanja podudaraju se $s$ rezultatima u našem istraživaju i upućuju na činjenicu da nema razlika između istraženih sistema. Unatoč tomu u literaturi smo pronašli da je sistem gutaperka/cement superiorniji od Resilona $^{\bullet}(31,32)$.

\section{Zaključak}

U uvjetima ovog istraživanja može se zaključiti da ni jedan sistem ne brtvi idealno apikalni prostor. Soft-Core ${ }^{\circ}$ je pokazao najslabije vrijednosti filtracije u usporedbi s ostalim grupama. Nije uočena velika razlika između ostalih grupa. Unatoč svemu potrebna su daljnja istraživanja koja bi potvrdila naše rezultate. two filler materials (guttapercha and Resilon ${ }^{\circ}$ ), with the definition of four groups: guttapercha / AH Plus ${ }^{\oplus}$, guttapercha / Epiphany, Resilon / AH Plus and Resilon / Epiphany. A fluid filtration technique was used to measure apical filtration. The authors found the lowest filtration values to correspond to the guttapercha / Epiphany group, followed by the guttapercha / AH Plus group. Nevertheless, there were no significant differences between guttapercha / AH Plus and Resilon / Epiphany. The authors therefore concluded that both combinations (which are those commonly used) show similar behavior.

Williamson et al. (28) compared Resilon ${ }^{\circ}$ Epiphany with guttapercha / $\mathrm{AH}$ Plus ${ }^{\circ}$ in assessing bacterial filtration using pathogen cultures and explored whether the plastic state of the two materials exerts an influence upon canal obturation. Specifically, these authors used the cold lateral condensation technique and the continuous wave technique developed by Buchanan. They concluded that there are no differences between the two materials or differences in performance attributed to the plastic conditions of guttapercha and Resilon .

In another study, Karapinar-Kazandağ et al. (29) compared obturation systems based on the monoblock concept (single cone / cement seeking adhesion to the canal walls, forming an obturation block). These systems were Resilon / Epiphany, EndoRez and Activ GP ${ }^{\bullet}$. The authors used a glucose filtration model and concluded that the monoblock materials are not superior to conventional guttapercha / sealing cement, since there were no statistically significant differences between them.

Melih et al. (30) compared Resilon versus guttapercha / $\mathrm{AH}$ Plus ${ }^{\circledR}$ and guttapercha / Acroseal ${ }^{\circ}$ (Septodont) to assess filtration, using methylene blue followed by longitudinal root sectioning for performing the measurements. They found guttapercha / Acroseal ${ }^{\circ}$ to produce significantly greater filtration that the other two systems. In turn, there were no significant differences between Resilon ${ }^{\circ}$ and guttapercha AH Plus ${ }^{\circ}$ - both of which afforded the best apical sealing performance.

As we have seen, the results of these studies coincide with our own findings in that they observe no differences among these obturation systems. Nevertheless, we have also found studies in which the performance of guttapercha / cement was reportedly superior to that of Resilon ${ }^{\circledR}(31,32)$.

\section{Conclusion}

Under the conditions of this study, it can be affirmed that although none of the systems produced perfect apical sealing, Soft-Core system showed significantly worse filtration results than the rest of the groups. There were no significant differences between the other groups. Nevertheless, further studies are needed in order to confirm our findings. 


\section{Abstract}

Aim: A comparison was made between the root canal lateral condensation technique and other condensation techniques in which physical (temperature: Soft-Core $\AA$, Obtura IIß) or chemical changes (condensation: Guttaflow $囚$, Resilon $®$ ) may affect the dimensional stability of obturation and thus favor apical microleakage. Materials and methods: A total of 212 single-root teeth removed for orthodontic or periodontal reasons were randomized to 5 groups of 40 teeth each. Six samples were used as positive controls, and another 6 as negative controls. The teeth were worked with the Hero 642 system, and each group was obturated using a different technique: lateral condensation, Obtura II®, Soft-Core $₫$, Guttaflow $®$ or Resilon $₫$. The samples were immersed in black ink, and after 72 hours the teeth were transparentized using the technique described by Robertson. Filtration of the ink was measured under the stereoscopic microscope. Analysis of variance and post-hoc testing were used for the statistical analysis.Results: The Soft-Core ${ }^{\circledR}$ obturated group showed significantly greater microleakage than the other groups, with no differences among the rest of the groups. Conclusions: Under the conditions of this study, the teeth obturated with the Soft-Core ${ }^{\circledR}$ technique showed greater apical microleakage than the other systems.
Received: April 9, 2014

Accepted: June 2, 2014

Address for correspondence Manuel Monterde

Catholic University of Valencia

Department of Endodontics

Valencia, Spain

clinicamonterde@gmail.com

Key words

Tooth Apex; Dental Leakage; Root Canal Obturation; Root Canal Filling Materials

\section{References}

1. Cohen, S; Hargreaves $\mathrm{K}$ - editors. Pathways of the pulp. $9^{\text {th }}$ ed. St. Louis: Mosby; 2006.

2. Schilder H. Filling root canals in three dimensions. Dent Clin North Am. 1967 Nov:723-44.

3. Fathia E, Hassan N, Yahia I. A comparative study of the microleakage of Resilon/Ephiphany and Gutta-percha/AH Plus obturating systems. Iran Endod J. 2012 Summer;7(3):139-43.

4. Kumar RV, Shruthi C. Evaluation of the sealing ability of resin cement used as a root canal sealer: an in vitro study. J Conserv Dent. 2012 Jul;15(3):274-7.

5. Kontakiotis EG, Wu MK, Wesselink PR. Effect of sealer thickness on long-term sealing ability: a 2-year follow-up study. Int Endod J. 1997 Sep;30(5):307-12.

6. Dummer PHM. Comparison of undergraduate endodontic teaching programs in the United Kingdom and in some dental schools in Europe and the United States. Int Endod J. 1991 Jul;24(4):16977.

7. Qualtrough AJ, Whitworth JM, Dummer PM. Preclinical endodontology: an international comparison. Int Endod J. 1999 Sep;32(5):406-14.

8. Robertson D, Leeb IJ, McKee M, Brewer E. A clearing technique for the study of root canal systems. J Endod. 1980 Jan;6(1):421-4.

9. De Moor RJ, Martens LC. Apical microleakage after lateral condensation, hybrid gutta-percha condensation and Soft-Core obturation: an in vitro evaluation. Endod Dent Traumatol. 1999 Oct;15(5):239-43.

10. De Moor RJ, Hommez GM. The long-term sealing ability of an epoxy resin root canal sealer used with five gutta-percha obturation techniques. Int Endod J. 2002 Mar;35(3):275-82.

11. De Moor RJ, De Bruyne MA. The long term sealing ability of AH 26 and $\mathrm{AH}$ Plus used with three gutta-percha techniques. Quintessence Int. 2004 Apr;35(4):326-31.

12. Lares C, EIDeeb ME. The sealing ability of the Thermafil obturation technique. J Endod. 1990 Oct;16(10):474-9.

13. Haikel Y, Freyman M, Fanti V, Claisse A, Poumier F, Watson M. Apical microleakage of radiolabeled lysozyme over time in three techniques of root canal obturation. J Endod. 2000 Mar;26(3):148-52.

14. Pommel L, Camps J. In vitro apical leakage of system B compared with other filling techniques. J Endod. 2001 Jul;27(7):449-51.

15. Abarca AM, Bustos A, Navia M. A comparison of apical sealing and extrusion between Thermafil and lateral condensation techniques. J Endod. 2001 Nov;27(11):670-2.

16. Gençoglu N, Garip Y, Bas M, Samani S. Comparison of different gutta-percha root filling techniques: Thermafil, Quick-fill, System $\mathrm{B}$ and lateral condensation. Oral Surg Oral Med Oral Pathol Oral Radiol Endod. 2002 Mar;93(3):333-6.

17. Boussetta F, Bal S, Romeas A, Boivin G, Magloire H, Farge P. In vitro evaluation of apical microleakage following canal filling with a coated carrier system compared with lateral and thermomecanical Gutta-Percha condensation techniques. Int Endod J. 2003 May;36(5):367-71.
18. Schafer E, Olthoff G. Effect of three different sealers on the sealing ability of both thermafil obturators and cold laterally compacted gutta-percha. J Endod. 2002 Sep;28(9):638-42.

19. Pallarés A. Estudio de la capacidad de sellado apical y adaptación a las paredes del conducto de la gutapercha termoplástica inyectada. Av Odontoestomatol. 1998(14):199-207.

20. Vizgirda PJ, Liewehr FR, Patton WR, McPherson JC, Buxton TB. A comparison of laterally condensed gutte-percha, thermoplasticized gutta-percha and mineral trioxide aggregate as root canal filling materials. J Endod. 2004 Feb;30(2):103-6.

21. Kqiku L, Miletic I, Gruber HJ, Anic I, Stadler P. Microleakage of root canal fillings with GuttaFlow and Resilon compared with lateral condensation. Wien Med Wochenschr. 2010 May;160(910):230-4.

22. Vasiliadis L, Kodonas K, Economides N, Gogos C, Stavrianos C. Short- and long-term sealing ability of Gutta-flow and AHPlus using an ex vivo fluid transport model. Int Endod J. 2010 May;43(5):377-81.

23. Irala Almeida MA, Adorno CG, Djalma Pecora J, Perdomo M, Pereira Ferrari PH. Evaluación de la filtración bacteriana en conductos radiculares sellados por tres diferentes técnicas de obturación. Endodoncia. 2010;28(3):127-134.

24. Elayouti A, Achleithner C, Lost C, Weiger R. Homogeneity and adaptation of a new gutta-percha paste to root canal walls. J Endod. 2005 Sep;31(9):687-90.

25. Tay FR, Loushine RJ, Weller RN, Kimbrough WF, Pashley DH, et al. Ultrastructural evaluation of the apical seal in roots filled with a policaprolactone-based root canal filling material. J Endod. 2005 Jul;31(7):514-9.

26. Biggs SG, Knowles KI, Ibarrola JL, Pashley DH. An in vitro assessment of the sealing ability of Resilon/Epiphany using fluid filtration. J Endod. 2006 Aug;32(8):759-61.

27. Onay EO, Ungor M, Orucoglu H. An in vitro evaluation of the apical sealing ability of a new resin-based root canal obturation system. J Endod. 2006 Oct;32(10):976-8

28. Williamson AE, Marker KL, Drake DR, Dawson DV, Walton RE. Resin-based versus gutta-percha-based root canal obturation: influence on bacterial leakage in an in vitro model system. Oral Surg Oral Med Oral Pathol Oral Radiol Endod. 2009 Aug;108(2):292-6.

29. Karapinar-Kazanda M, Tanalp J, Bayrak OF, Sunay H, Bayirli G. Microleakage of various root filling systems by glucose filtration analysis. Oral Surg Oral Med Oral Pathol Oral Radiol Endod. 2010 Jun;109(6):e96-102.

30. Melih I, Jakovljević A, Popović M, Pesić D. Comparative evaluation of sealing ability of different obturation materials. Srp Arh Celok Lek. 2010 May-Jun;138(5-6):287-91.

31. Hirai VH, da Silva Neto UX, Westphalen VP, Perin CP, Carneiro E, Fariniuk LF. Comparative analysis of leakage in root canal fillings performed with gutta-percha and Resilon cones with AH Plus and Epiphany sealers. Oral Surg Oral Med Oral Pathol Oral Radiol Endod. 2010 Feb;109(2):e131-5.

32. Santos J, Tjäderhane L, Ferraz C, Zaia A, Alves M, De Goes M et al. Long-term sealing ability of resin-based root canal fillings. Int Endod J. 2010 Jun; 43(6):455-60. 